\title{
Subak Local Wisdom as Social Studies Learning Source in Junior High School
}

\author{
I Putu Sriartha*, I Wayan Kertih \\ Faculty of Law and Social Sciences \\ Universitas Pendidikan Ganesha \\ Singaraja, Indonesia \\ *putusriartha@gmail.com, iwayankertih@gmail.com
}

\begin{abstract}
Subak local wisdom is the Balinese agricultural culture that has been declared by UNESCO as a world cultural heritage. Subak which is based on the philosophy of Tri Hita Karana has social, religious and ecological values and serves as the basis for a harmonious community life. This study aims to determine: (1) the level of knowledge and understanding of social studies teachers about subak, and (2) social studies teachers' attitude towards the idea about developing social studies learning models based on subak local wisdom. The study sample consisted of social studies teachers who were determined by purposive sampling. The research instruments were a semi-structured test and attitude questionnaire based on the Likert scale. Data were analyzed by quantitative descriptive techniques. The results showed that: (1) the majority of the teachers had a low level of knowledge and understanding about subak (47.50\%); the remaining $32.50 \%$ are classified as moderate and only $20 \%$ are classified as high. (2) The majority of the teachers $(77.50 \%)$ stated that they never used subak as a social study learning resource. (3) The teacher's attitude towards the idea of developing the social studies learning model based on subak local wisdom was very positive, where $97.50 \%$ expressed a strong agreement. The implication of the research is that further research needs to be done with a focus on developing social studies learning models based on the local wisdom of subak.
\end{abstract}

Keywords: subak, social studies learning

\section{INTRODUCTION}

Indonesia has a variety of local cultures with their respective unique local wisdoms. The use of local wisdoms in social studies learning has a strategic role in developing character, students' social literacy, and ecological intelligence in overcoming problems of environmental damage [1-3]. Education and teaching that are based on local wisdom can develop cultural identity and simultaneously strengthening the local wisdoms existence itself in facing the challenges of the global cultures [4]. The community local wisdom absolutely has to be used as the learning resource at school because it is capable of enhancing students' ability in relation to understanding the relation between the real life and what they learn at school. Through local wisdom the students learn about their cultural values which shape attitude, behavior, and thinking skill [5]. The use of the community local wisdom in learning can integrate modern science into traditional knowledge and can create a meaningful learning and effective teaching materials $[6,7]$.

The development of local wisdom as the source and model of teaching at school (including social studies) has only been attempted by a few teachers [5]. The development of social studies learning based on local wisdom can be used as a correction to the weaknesses of today's social studies learning that still focuses on the academic aspect, thus is less contextual and has not yet been capable of facilitating the students to use modern technology critically in accordance with their culture. The academic nature is marked by the emphasis on material, not on competence, by the lack of orientation toward the sharpening of logical and critical thinking, the lack of the arousal of curiosity, the lack of activities of problem solving and the lack of social skill development and the fact that the learning occurs in a less joyful atmosphere. The learning is less contextual because it prioritizes the discussion of global issues that are less related to the real problems in the local environment. These weaknesses confirm the opinion of Ismail et al. [8] who see the weakness in social studies education from two aspects. First, from the aspect of substance, conceptual sources and empirical sources that become the substantial reference for social sciences education are too curriculumcentered and ignore local wisdoms as their substances. Secondly, from the aspect of learning, social studies learning at school produces instrumental output that is not powerful, does not give the opportunity to the students to empower themselves, based more on the formal need than the students' real need, and is very boring.

One of the local wisdoms of the local Balinese community that is relevant to be used as learning resources is subak. Subak local wisdom is Balinese community agricultural culture that is very well-known and has been declared by Unesco as a world cultural heritage. Subak is based on the philosophy of Tri Hita Karana (THK), that means three components of the cause of happiness in life $($ Tri $=$ Three; Karana $=$ cause Hita $=$ happiness). The three components are: (1) parhyangan that regulates the harmonious relation between human beings and God, (2) pawongan that regulates the harmonious relation among human beings, (3) palemahan that regulates the harmonious relation between human beings and the natural environment. These three components contain the basic values 
of a harmonious community life, i.e., religious value, social relation value (humanity) and environment conservation value (ecological) [9-11]. These basic values have relevance and significance to the scope and objectives of social sciences education.

This article is the first part of the result of study on developing social studies learning model at junior high school based on the subak local wisdom. The objectives of the first part are to analyze the character values in subak, to describe knowledge and understanding of social studies teachers about subak local wisdom, and to know teachers' attitude toward the use of subak as sources and model for social studies learning.

\section{METHODS}

The method used to reach the objectives of the study was a survey method of the descriptive qualitative type. The main data were in the form of qualitative data related to the realization of the implementation of the THK philosophy and character values in subak, the teachers' knowledge, and understanding of subak, and the teachers' attitude toward the idea of developing a social study learning model based on subak. Research subjects were 40 social studies teachers in 18 junior high schools in Buleleng Regency and three administrators of the Subak Sambangan as key informants that determined purposively. The instruments used were semistructured questionnaire, knowledge and understanding test, attitude questionnaire that uses Likert scale. The data were collected by using an observation technique, interview, and document analysis. The data analysis was done following the stages of data description, data reduction, categorization, and interpretation and construction.

\section{RESULTS AND DISCUSSION}

\section{A. Character Values in SUBAK Local Wisdom}

Subak is basically an organization or an association of farmers who manage irrigation water and planting system based on the philosophy of Tri Hita Karana. THK is Balinese philosophy that originated from the Hindu teaching. The Hindu Balinese community believes that happiness or welfare in life can be reached by creating a harmony and balance in relation between human beings and God (parhyangan), relation among human beings (pawongan), and between human beings and the natural environment (palemahan). The character values in subak can be dug by analyzing the realization of the implementation and function of the three components of the THK (parhyangan, pawongan, and palemahan).

The realization of the implementation of the parhyangan component in subak is seen from the presence of religious rituals and holy places (temples) that has a hierarchical pattern. The ritual meaning, basically, is the expression of thankfulness to God for the bounties given by him in the form of fertilized soil, water and crops. While the holy place or subak temple has the function as the place that connects the subak members to God the Creator. In addition, the ritual activities and subak temple have a social function (as the reinforcer of strength / unifier of collective life and as something that prevents conflicts), and the ecological function (as the controller against pests and plant diseases, and the preserver of the ecosystem $[12,13]$. Subak temples also have a function as a spiritualcontrol mechanism (God) for irrigation management carried out by subak [14]. This function always makes subak members behave honestly because they are afraid of God's punishment (karmaphala law) if they do bad in irrigation water management. Karmaphala law is a punishment from God against humans according to their actions.

The realization of the implementation of the pawongan is apparent through collective activities that are realized through social communications and interactions. Collective activities in subak cover the aspects of organization, attending meetings, using rights and responsibilities, using sanctions, mutual work to make the subak programs successful and internal and external conflicts managements. In addition to social activities, there are also social infrastructure/ facilities such as a bale /subak office, subak road, and tools that belong to subak. The social activities in subak are regulated through awig-awig and the principle of paras paros sarpanaya sagilik saguluk selunglung sebayantaka.

Awig-awig is one of the cultural capitals and social capitals that are very important to create order/ peace in subak. Awigawig subak is strictly obeyed by subak members because it is a rule that is directly applied (rule in use) and contains socioreligious sanctions and material sanctions that are quite heavy. The principle of parasparos sarpanaya sagilik saguluk selunglung sebayantaka has two meanings, first, parasparos sarpanaya, which means we are part of others, and others are part of us (the same in meaning as helping each other, trusting each other, and respecting each other). Sagilik saguluk selunglung sabayantaka means good or bad, alive or dead we shoulder the responsibility together (the same in meaning as having one fate). Comprehensively, paras-paros sarpanaya sagilik saguluk selunglung sebayantaka is the principle that respecting the spirit of mutual help, helping each other, trusting each other, and the feeling of one fate. This principle is almost the same as the meaning of a popular expression in Indonesia, that is: "berat sama dipikul, ringan sama dijinjing, berdiri sama tinggi dan duduk sama rendah". The obligations of subak members are regulated based on the right to irrigation water and its position in the subak organization. The form of obligation among subak members must be present in subak activities called ngayah, pay routine fees at the end of the year called sarin tahun, and pay management fees when needed (incidental) called pepesuan.

The component of pawongan is implemented in the form of the activities of maintenance and management of subak infrastructure/facilities, such as irrigation ditches, water division and distribution, regulating the planting schedule, and maintenance of plants based on the principle of justice and togetherness. Irrigation water division is done by using the tektek system which reflects justice based on the area of the rice field and the system in which more water is allotted to farmers in the location away from the water source. The water distribution uses the queuing system according to location, 
planting schedule, and season. Maintenance of plants and pest control are done by using a religious approach called nangkluk merana (driving the pest away) using the natural cycle system called kerta masa (growing one type of plant at the same time in the subak region). The structure of the irrigation water distribution building (called tembuku) is made with a numbak system that reflects justice in the right to get water. Subak also adopts a pelampias system, namely: providing irrigation water assistance for members of the subak whose location in the downstream rice fields. In every rice field block the inlet must be made and outlets to make it possible to borrow and borrow water to overcome water scarcity.

Based on the analysis of the forms of the implementation of each of the THK components in subak, major character values that are contained in them can be identified. The character values are presented in Table I.

TABLE I. CHARACTER VALUES IN THE SUBAK THK PHILOSOPHY

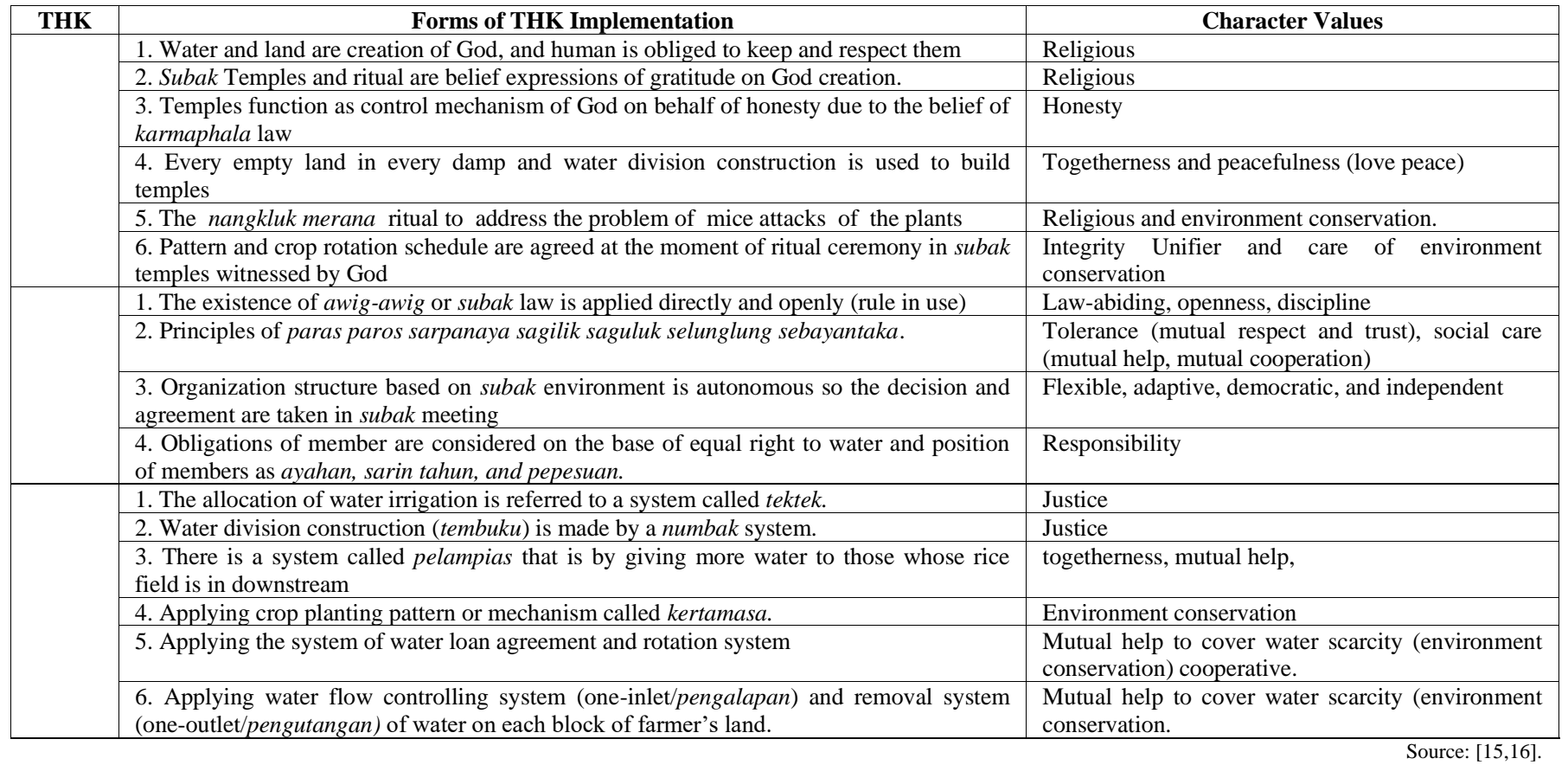

\section{B. Teachers' Knowledge About SUBAK}

The teachers' knowledge and understanding are measured from their abilities to define something on subak, describing the types of religious ritual in subak, types of subak temples, drawing a sketch of the subak region, digging down the meaning and functions of the subak religious rituals, understanding in depth the life values contained in the pawongan activities contained in the palemahan activities.

The results showed that $47.50 \%$ of the teachers have a low level of knowledge and understanding; $32.50 \%$ are categorized as average and $20.0 \%$ high. This shows that most of the teachers have not yet known and understood things about subak. The teachers can only describe the types of temples and subak rituals, while the low level of knowledge and understanding are located in three aspects First, not yet able to formulate the concept of subak correctly; secondly, not yet able to draw a sketch map of subak regions; thirdly, not yet able to dig down or interpret the meaning and functions of life behind the activities and artefacts that exist in subak.

Ten percent of the teachers are able to formulate the definition of subak correctly, while $80 \%$ of them formulated the definition of subak wrongly. The definition of subak that was evaluated as correct if it contains the three aspects: religious aspect (the parhyangan component), social economical aspect (the pawongan component), and the environmental aspect (the palemahan component). Table 2 shows the examples of comparison in the formulation of definition of subak given by the teachers that is correct and the one that is wrong.

TABLE II. WRONG AND CORRECT EXAMPLES OF THE DEFINITION OF SUBAK FROM THE RESULT OF THE SOCIAL STUDIES TEACHERS' WORK

\begin{tabular}{|c|c|}
\hline $\begin{array}{c}\text { Wrong Formulation of } \\
\text { Definition }\end{array}$ & $\begin{array}{c}\text { Correct Formulation of } \\
\text { Definition }\end{array}$ \\
\hline $\begin{array}{l}\text { Subak is (1) a water division in the } \\
\text { agricultural environment, (2) an } \\
\text { organization whose members are } \\
\text { all farmers from a certain village, } \\
\text { (3) a region with rice fields that a } \\
\text { group of people have, (4) an } \\
\text { organization that consists of } \\
\text { farmers, both the owners and the } \\
\text { workers. }\end{array}$ & $\begin{array}{l}\text { (1) Subak is a traditional } \\
\text { organization that is based on uger- } \\
\text { uger or regulations based on the } \\
\text { Tri Hita Karana. (2) Subak is a } \\
\text { legal community that has a socio- } \\
\text { religious characteristic that } \\
\text { historically has grown and } \\
\text { developed as an agricultural water } \\
\text { use system organization. }\end{array}$ \\
\hline
\end{tabular}


On table II is seen that the correct definition (the first definition) has the expression Tri Hita Karana that reflects the religious, socio-economic and ecological aspects. So is in the second definition there is a socio-religious aspect and a water use system as representations of the Tri Hita Karana philosophy. In the wrong formulation of the definition there are no complete religious, socio-economic and ecological aspects. For example, in the first definition, it is only stressing the environmental aspect; the second definition and the fourth definition only puts an emphasis on the social aspect.

Secondly, the lack of knowledge and understanding on the part of the teachers is shown by the inability to draw a sketch map of subak region with its complete elements. The correct sketch should contain a subak temple (the parhyangan component), rice field area and irrigation ditches (the palemahan component) and farmers (the pawongan component). It was observed the sketch made by teachers only contains the subak area that does not have the parhayangan component the pawongan component and the palemahan component. A subak map can be used as one of the teaching material resources for social science that is contextual and factual. The ability to draw a sketch map of a subak region correctly consists of the sub-components of ability in knowledge, understanding, analysis and evaluation.

In a subak culture-based learning various forms material such as in the form of poster, landscape map, subak region landscape, video, photo, narration, cross cultural module, and cross-cultural book. A subak based learning that takes the form of various learning materials is very meaningful in developing the ability in knowledge, understanding, analysis, application and creation [6].

The third problem in knowledge and understanding is the fact that most of the teachers have not been able to understand in depth or interpret the meanings and functions of the forms of application of each of the components of the Tri Hita Karana in subak. The ability to catch the meaning behind the symbols that subak has is very important since the meaning can be used as a model in living a daily life to create a harmonious community life. Like what is expressed by 12], that the activities and artefact of subak that is full of symbols have very positive meanings in life. It is explained that the ritual activities and the network of subak temples have the social function (as the reinforcer / unifier of collective life and something for preventing conflicts) and an ecological function (as the control of pest and plant diseases, and it conserves the ecosystem (the ecological function).

\section{The Teachers' Attitude toward the Development of Social Studies Learning Model Based on SUBAK Local Wisdom}

Although the teachers' knowledge and understanding of subak was limited, they gave their response to the idea of developing social studies learning model based on subak local wisdom. Almost all teachers (39 teachers/ 97.50\%) said that they agree, while there was only 1 teacher $(2.50 \%)$ expressed that he less agreed, while none disagreed. The positive teachers' attitude can be interpreted that basically they had a commitment and desire to integrate it into social science teaching in which subak system serves as a learning resource.
However, because of their limited insight and understanding about subak, they had difficulty in implementing it in the teaching. The limited insight and understanding about subak system caused among other things by the scarcity of information sources about subak that can be accessed by the teachers. Especially in the form of learning materials such as handout, textbook, video about subak life, study reports, and other sources of information. The result of this study brings the implication about the stakeholders, including universities to give experiences in the form of collaborative studies and training that are related to developing a social science teaching model and teaching materials based on subak local wisdom.

In its implementation, the teachers were aware that there were some constraints that needed to be addressed. According to the teachers, the constraints faced when using the subak system in social studies learning are: (1) schools are far from the subak location, especially the schools in town, (2) the lesson period is limited, while there is a need to learn directly from the subak, (3) the knowledge and understanding about subak is limited, (4) sources of references about subak are rare, and (5) it is difficult to find resource persons on subak. If these constraints are considered carefully, the constraints told by the teachers are empirically realistic, the solution to the constraints can be found. For example, by making a video or film about subak, the provision of teaching materials about subak, and once or twice in a semeter the students are asked to do an outdoor study to the nearest subak. Schools in the villages that are close to a subak can run the outdoor study more often.

The result of this study also notes the teachers' opinions about activities that need to be done before learning with subak learning resources. Based on a brainstorming it was found that basically there are five stages of the main activities that need to be done. First, to make a preparation in the form of teaching materials (syllabus, lesson plans, student worksheet), preparing subak teaching material, media about subak (by prioritizing multimedia or video/film) Secondly, to run a worship on an indepth study about subak by inviting resource persons (subak expert or subak organizer). Thirdly, the classroom teaching by using subak as the learning resources. Fourthly, to ask students to make observation, interview, and documentation in the subak location that is the closest to the school. Fifthly, to do an evaluation of the learning.

\section{CONCLUSION}

Subak local wisdom that has been declared a world cultural heritage is very relevant to be selected as learning resources and the model for social science teaching at junior high schools for developing the nation's character. In it, there are 17 characters' values: religiosity, honesty, solidarity, love for peace, integrity, care for the environment, social concern, openness, adherence to laws, discipline, tolerance, mutual help, democracy, flexibility, adaptiveness, responsibility and justice.

The knowledge and understanding of the social science teachers about subak is still low. It was noted that there were $47.50 \%$ of the teachers had a low level of knowledge and understanding, falling into the medium category $(32.50 \%)$, and only $20 \%$ of them had a high category. The low level of the knowledge and understanding about subak system is found in 
[3] Hetharion, D.S. Bety, N. Supriatna, E. Wiyanarti and R. Wiriatmadja, “ Inheritance of Values of Local Wisdom Cuci Negeri through Social Studies Learning: A story from Ambon," 3rd Asian Education Symposium (AES), Advances in Social Science, Education and Humanities Research, vol. 253, pp. 259-263, Atlantis Press, 2018.

[4] D. Astuti and S. Irene, "Kearifan Lokal Sebagai Modal Sosial dalam Pendidikan Karakter di Sekolah," Makalah disampaikan dalam Seminar Nasional Pengembangan dan Pengelolaan Pendidikan Berbasis kearifan Lokal Tanggal 11 Juli 2012, Universitas Negeri Makasar, 2012.

[5] Rochman, Chaerul, D. Nasrudi, R. Rokayah, N. Hermita, A. Malik and I. Suhada, "Integration of Local Wisdom in Science Learning", In Proceedings of the 2nd Asian Education Symposium (AES), pp. $424-$ 428, SCITEPRESS - Science and Technology Publications, Lda.,2018.

[6] K. Surata and S. Putu, "Pembelajaran Lintas Budaya: Pemanfaatan Subak sebagai Model Ecopedagogy," Jurnal Kajian Bali, vol. 03, no. 02 pp. 181-198, 2013.

[7] I.W. Suastra, "Balinese Local Wisdom and Their Implication in Science Education at School". International Research Journal of Management, IT, and Social Sciences (IRJMIS), vol. 4, Issue 2, pp. 42-50, 2017.

[8] M. Ismail, Sukardi and S. Surachman, "Pengembangan Model Pembelajaran Berbasis kearifan Lokal Masyarakat Sasak: Ke arah sikap dan Perilaku Berdemokrasi Siswa SMP/MTs," Jurnal Pendidikan dan Pengajaran, Jilid 142, no. 2, pp. 137, 2009.

[9] I.P. Sriartha and S.R. Giyarsih, "Spatial Zonation Model of Local Irrigation System (A Case of Subak System in Bali)," Indonesian Journal of Geography, vol. 47, no. 2, pp. 142-150, 2015.

[10] I.P. Sriartha and S.R. Giyarsih, "Subak Endurance in Facing External Development in South Bali, Indonesia”, International Research Journal of Management, IT \& SocialSciences (IRJMIS), vol. 4, Issue 4, pp. 20 30, 2017.

[11] W. Windia and W.A.A. Wiguna, Subak Warisan Budaya Dunia. Denpasar: Udayana Universaity Press, 2013.

The authors would like to express thanks to the Rector and Head of Research and Community Work Institution, Ganesha University of Education who have granted a financial aid and a permission to do the study. Deeply appreciated to the social science teachers at junior high schools in Buleleng regency for their cooperation so that this study could be finished satisfactorily.

\section{REFERENCES}

[1] R. Rokoyah and C. Rochman, " Local Wisdom on the Social Science Literacy in Elementery Education," 3rd Asian Education Symposium (AES), Advances in Social Science, Education and Humanities Research, Volume 253 (pp. 149-151), Atlantis Press, 2018.

[2] A. Sofyan, "Ecological Intelligence Based on Local Wisdom of Tidung Tribe Tarakan in Social Studies Learning", In Proceedings of the 2nd Asian Education Symposium (AES) (pp. 223-227), 2017.

[12] J.S. Lansing, 1987. "Balinese Water Temples and the Management of Irrigation," American Anthropologist, vol.89, no. 2, pp. 326-341, 1987.

[13] Sutawan, Nyoman, Subak Organisation and Management in Bali, Denpasar: Pustaka Bali Post, 2008.

[14] Windia, Wayan, Sumiati, Gede Sedana, "Aspek Ritual Pada Sistem Irigasi Subak Sebagai Warisan Budaya Dunia,” Jurnal Kajian Bali, vol. 05, no. 01, pp. 23-56, April 2015.

[15] I.P. Sriartha, I.N. Jampel, I.G.A. Wesnawa and I.W. Widiana, "Local Wisdom of Subak as A Model of Character Building for Social Studies learning in Schools," Proceeding, The 2nd International Conference on Innovative research Across Diciplines. Sanur, Bali: Atlantis Press, 2017.

[16] I.P. Sriartha and I.W. Kertih, "Pemanfaatan Kearifan Lokal Sistem Subak Sebagai Model Pembelajaran IPS Berbasis Etnopedagogi Pada Sekolah Menengah Pertama Di Kabupaten Buleleng Bali," Laporan Penelitiani. Singaraja: Pascasarjana Universitas Pendidikan Ganesha, 2017, unpublished. 